\title{
Granulomatous lobular mastitis
}

\author{
J J GOING, T J ANDERSON, S WILKINSON,* U CHETTY* \\ From the Departments of Pathology and *Clinical Surgery, University of Edinburgh, Scotland
}

SUMMARY The clinical and pathological features of nine cases of granulomatous mastitis were compared with those of 10 cases of duct ectasia/periductal mastitis (DE/PM), all of which were associated with active granulomatous inflammation. Granulomatous mastitis affects a younger age group, and although there is some overlap with DE/PM, it has distinctive pathological features, particularly a lobule centred distribution, for which the term "granulomatous lobular mastitis" is recommended. There is a strong tendency for persistence or recurrence. Our cases of granulomatous mastitis all occurred in parous women, five of them within three years of pregnancy.

Awareness of this condition is important, because surgery does not offer the best treatment of recurrent disease, and trials of adequate drug treatment, including corticosteroids, are required.

Granulomatous mastitis was first clearly described as a separate entity in 1972 by Kessler and Wolloch, ${ }^{1}$ who reported five women, in whom breast masses were due to a florid, sometimes necrotising, granulomatous lobulitis that was not associated with trauma, specific infection, or exogenous material. Since then, the largest published series has been that of Fletcher et $a l^{2}$ (seven cases); smaller series or individual cases have been reported by Koelmeyer and MacCormick, ${ }^{3}$ Cohen, ${ }^{4}$ Brown and Tang, ${ }^{5}$ DeHertogh et al, ${ }^{6}$ Carmalt and Ramsey-Stewart, ${ }^{7}$ and Rowe. ${ }^{8}$ Cases probably representing this entity can be found in reports published before $1972.9^{10}$ An association with pregnancy and lactation has been noted and reemphasised recently. ${ }^{11}$

The pathogenesis of granulomatous mastitis is unclear, as is its relation to the duct ectasia/periductal mastitis (DE/PM) group of conditions, in which a granulomatous inflammatory component may be present. This study aimed to examine the clinical and pathological association between granulomatous mastitis and the granulomatous variants of DE/PM.

\section{Material and methods}

We reviewed nine cases of granulomatous mastitis biopsied in Edinburgh from 1975-86 and compared them with 10 cases of DE/PM in which there was prominent granulomatous inflammation. Some of the DE/PM group had been identified in connection with a separate study of mammary duct ectasia. ${ }^{12}$ The notes were obtained for all cases and the clinical data reviewed. The slides were obtained for all biopsy specimens, and where necessary, the blocks were recut and restained. Special stains (Gram, Ziehl-Neelsen, and Grocott's methenamine silver method) were examined for organisms. In four of the cases of granulomatous mastitis (cases 2, 4, 8 and 9) and one case of DE/PM (case 11) in which further biopsies were performed, fresh tissue was submitted for microbiological examination, including culture for Mycobacterium tuberculosis. In these and a further four cases wound swabs were also submitted. Special transport media were not used.

\section{Results}

\section{CLINICAL DATA}

Table 1 gives the clinical features for both groups of patients; table 2 summarises some of the data and gives, for comparison, data from published cases of granulomatous mastitis. ${ }^{1-10}$ Noteworthy features were the relative youth of the patients with granulo: matous mastitis compared with the age of the cases of $\mathrm{DE} / \mathrm{PM}$, and the fact that they were all parous, unlike the DE/PM group. The frequency with which malignant disease was clinically diagnosed in the patients with granulomatous mastitis was particularly striking given the youth of these patients, and contrasts with the patients with DE/PM in whom cancer was clinically diagnosed much more infrequently despite their greater mean age. Most patients with granulomatous mastitis underwent more than one operation, and this too contrasted with the experience of the patients with DE/PM. 
Table 1 Clinical data for patients with granulomatous mastitis or $D E / P M$

\begin{tabular}{|c|c|c|c|c|c|c|c|c|c|c|c|}
\hline & Age & Parity & $\begin{array}{l}\text { Years } \\
\text { since last } \\
\text { delivery }\end{array}$ & $\begin{array}{l}\text { Size } \\
\text { of lesion } \\
(\mathrm{cm})\end{array}$ & Side & $\begin{array}{l}\text { Clinical } \\
\text { diagnosis }\end{array}$ & $\begin{array}{l}\text { Breast } \\
\text { feeding }\end{array}$ & $\begin{array}{l}\text { Contraceptive } \\
\text { pill use }\end{array}$ & Bacteriology & $\begin{array}{l}\text { No of } \\
\text { biopsies }\end{array}$ & Other data including drug use \\
\hline \multicolumn{12}{|c|}{ Patients with granulomatous lobular mastitis (GM) } \\
\hline 1 & 17 & $1+0$ & $0 \cdot 2$ & 6 & $\mathbf{R}$ & Malignant & No & Never & & 1 & \\
\hline 2 & 23 & $3+1$ & $2 \cdot 5$ & 6 & $\mathbf{L}$ & Malignant & Yes & Former user & Negative* & $1+\dagger$ & $\begin{array}{l}\text { Prolactin normal, chest } x \text {-ray } \\
\text { Kveim test negative; positive } \\
\text { tuberculin test }\end{array}$ \\
\hline 3 & 26 & $2+0$ & 3 & $0 \cdot 5$ & $\mathbf{R}$ & Benign & No & Current user & & 1 & \\
\hline 4 & 26 & $3+0$ & $0 \cdot 8$ & 2 & $\mathbf{L}$ & Benign & No & Current user & Negative* & 2 & $\begin{array}{l}\text { Associated polyarthralgia }+ \\
\text { erythema nodosum chest } x \text {-rá } \\
\text { Kveim test negative }\end{array}$ \\
\hline 5 & 28 & $1+0$ & 1 & $4 \cdot 5$ & $\mathbf{R}$ & Malignant & Yes & Former user & Negative & 2 & \\
\hline 6 & 29 & $4+3$ & 7 & 1 & $\mathbf{L}$ & Benign & No & Former user & & $\overline{1}$ & 3 \\
\hline 7 & 30 & $2+0$ & 0.5 & 3 & $\mathbf{R}$ & Benign & Yes & & & 1 & \\
\hline 8 & 35 & $2+4$ & 15 & 8 & $\mathrm{~L}$ & Malignant & Yes & Former user & $S$ aureus $\times 1^{*}$ & $2+t$ & $\begin{array}{l}\text { Gross phenothiazine induced } \\
\text { hyperprolactinaemia } \\
(4240 \mathrm{mU} / 1)\end{array}$ \\
\hline 9 & 42 & $4+1$ & 15 & 2 & $\mathbf{R}$ & Benign & Yes & Former user & Negative* & $2+t$ & Prolactin normal \\
\hline \multicolumn{12}{|c|}{ Patients with duct ectasia/periductal mastitis (DE/PM) } \\
\hline 10 & 29 & $1+0$ & 1 & 2 & $\mathbf{L}$ & Benign & No & Former user & $S$ aureus $\times 1$ & $2+\dagger$ & \\
\hline 11 & 31 & $1+1$ & 1 & 5 & $\mathbf{L}$ & Benign & No & Former user & Negative* & 1 & \\
\hline 12 & 34 & $1+0$ & 4 & 1 & $\overline{\mathbf{R}}$ & Benign & Yes & Never & Negative & 1 & \\
\hline 13 & 42 & $0+0$ & & 4 & $\mathbf{R}$ & Benign & & Never & & 1 & \\
\hline 14 & 45 & $1+0$ & 27 & $3 \cdot 5$ & $\mathbf{R}$ & Benign & $?$ & Never & & 1 & 8 \\
\hline 15 & 48 & $0+0$ & & 4 & $\dot{L}$ & Malignant & & Never & Negative & 1 & \\
\hline 16 & 51 & $3+1$ & 14 & $i$ & $\mathbf{R}$ & Benign & Yes & Never & & 2 & $\bar{c}$ \\
\hline 17 & 53 & $2+0$ & 23 & 4 & $\mathrm{~L}$ & Benign & $?$ & Never & & 1 & \\
\hline 18 & 53 & $1+0$ & 30 & 4 & $\mathbf{L}$ & Benign & $?$ & Never & & 1 & \\
\hline 19 & 65 & $2+0$ & 38 & 1 & $\overline{\mathbf{L}}$ & Malignant & $?$ & Never & & 1 & 4 \\
\hline
\end{tabular}

${ }^{*}$ Culture of fresh tissue obtained at biopsy; †additional drainage procedures without tissue excision.

Table 2 Mean value and range for variables of all cases of granulomatous mastitis and $D E / P M^{*}$

\begin{tabular}{|c|c|c|c|c|c|}
\hline & & Age & Parity & $\begin{array}{l}\text { Years since last } \\
\text { delivery }\end{array}$ & $\begin{array}{l}\text { Size of lesion } \\
(\mathrm{cm})\end{array}$ \\
\hline Granulomatous mastitis & $\begin{array}{l}\text { Sample size } \\
\text { Mean } \\
\text { Range }\end{array}$ & $\begin{array}{l}9 \\
28 \cdot 4 \\
17-42\end{array}$ & $\begin{array}{l}9 \\
2 \cdot 4 \\
1-4\end{array}$ & $\begin{array}{l}9 \\
5 \cdot 0 \\
0 \cdot 2-15\end{array}$ & $\begin{array}{l}9 \\
3 \cdot 7 \\
0 \cdot 5-8\end{array}$ \\
\hline $\mathrm{DE} / \mathrm{PM}$ & $\begin{array}{l}\text { Sample size } \\
\text { Mean } \\
\text { Range }\end{array}$ & $\begin{array}{l}10 \\
45 \cdot 1 \\
29-65\end{array}$ & $\begin{array}{l}10 \\
1 \cdot 2 \\
0-3\end{array}$ & $\begin{array}{l}8 \\
17 \cdot 3 \\
1-38\end{array}$ & $\begin{array}{l}10 \\
3 \cdot 0 \\
1-4\end{array}$ \\
\hline Published cases of granulomatous mastitis & $\begin{array}{l}\text { Sample size } \\
\text { Mean } \\
\text { Range }\end{array}$ & $\begin{array}{l}23 \\
33 \\
22-42\end{array}$ & $\begin{array}{l}22 \\
3 \cdot 1 \\
1-6\end{array}$ & $\begin{array}{l}21 \\
2 \cdot 1 \\
0 \cdot 1-6 \cdot 5\end{array}$ & $\begin{array}{l}9 \\
5 \cdot 6 \\
2 \cdot 5-8\end{array}$ \\
\hline
\end{tabular}

*Sample sizes vary for published cases because complete data are not available for all patients.

HISTOLOGICAL DATA

The character of the inflammatory process was similar in all the cases studied, but the distribution was clearly different (table 3). Granulomatous mastitis showed a predominantly lobular spread (fig 1), which was inconspicuous in DE/PM. In all cases epithelioid macrophages, Langhans'-type giant cells, and often neutrophil polymorphs were present in the granulomas, with attendant lymphocytes, plasma cells, and eosinophils in varying numbers. Clear round spaces (fig 2), presumably representing lipid, were occa- sionally noted, sometimes within granulomata, and in some cases foamy histiocytes replete with lipid were conspicuous. In both groups the inflammatory infiltrate was often sufficiently acute and intense to produce microabscess formation (fig 3 ). In these areas it was impossible to relate the inflammatory response to pre-existing parenchyma, as there was complete breakdown of the tissue. No evidence of a primary vasculitis was seen in any case, although vascular changes apparently secondary to the heavy inflammation were seen in some areas (cases 
Table 3 Histological features

\begin{tabular}{|c|c|c|}
\hline $\begin{array}{l}\text { Distribution and relative } \\
\text { intensity of inflammation }\end{array}$ & $\begin{array}{l}\text { Maximum intensity } \\
\text { of inflammation }\end{array}$ & $\begin{array}{l}\text { Presence of } \\
\text { duct dilatation }\end{array}$ \\
\hline \multicolumn{3}{|c|}{ Patients with granulomatous lobular mastitis (GM): } \\
\hline $1 \mathrm{~L}>\mathrm{LD}$ & Heavy & No \\
\hline $2 \mathrm{LD}>\mathrm{L}$ & Heavy & No \\
\hline $3 \quad \mathrm{LD}>\mathrm{L}>\mathrm{P}$ & Heavy & Yes (minor) \\
\hline $4 \mathrm{~L}=\mathrm{LD}$ & Heavy & No \\
\hline $5 \mathrm{~L}>\mathrm{LD}$ & Heavy & No \\
\hline $6 \mathrm{LD}>\mathrm{L}=\mathrm{P}$ & Moderate & No \\
\hline $7 \mathrm{~L}>\mathrm{P}=\mathrm{LD}$ & Heavy & Yes \\
\hline $8 \mathrm{~L}>\mathrm{LD}$ & Heavy & No \\
\hline $9 \mathrm{LD}>\mathrm{L}$ & Heavy & No \\
\hline \multicolumn{3}{|c|}{ Patients with duct ectasia/periductal mastitis (DE/PM): } \\
\hline $10 \mathrm{P}$ & Heavy & Yes \\
\hline $11 \mathrm{LD}>\mathrm{P}=\mathrm{L}$ & Heavy & Yes (minor) \\
\hline $12 P=L D>L$ & Heavy & Yes \\
\hline $13 P>L$ & Light & Yes \\
\hline $14 \mathrm{P}$ & Light & Yes \\
\hline $15 \mathrm{P}>\mathrm{LD}$ & Heavy & Yes* \\
\hline 16 LD $>P>L$ & Heavy & Yès \\
\hline $17 \mathrm{LD}=\mathrm{P}>\mathrm{L}$ & Heavy & Yes \\
\hline $18 \mathrm{P}$ & Heavy & Yes \\
\hline $19 \mathrm{P}$ & Heavy & Yes \\
\hline
\end{tabular}

$\mathrm{L}=$ lobule centred; $\mathrm{P}=$ periductal; $\mathrm{LD}=$ locally diffuse disease not referable to parenchymal structures.

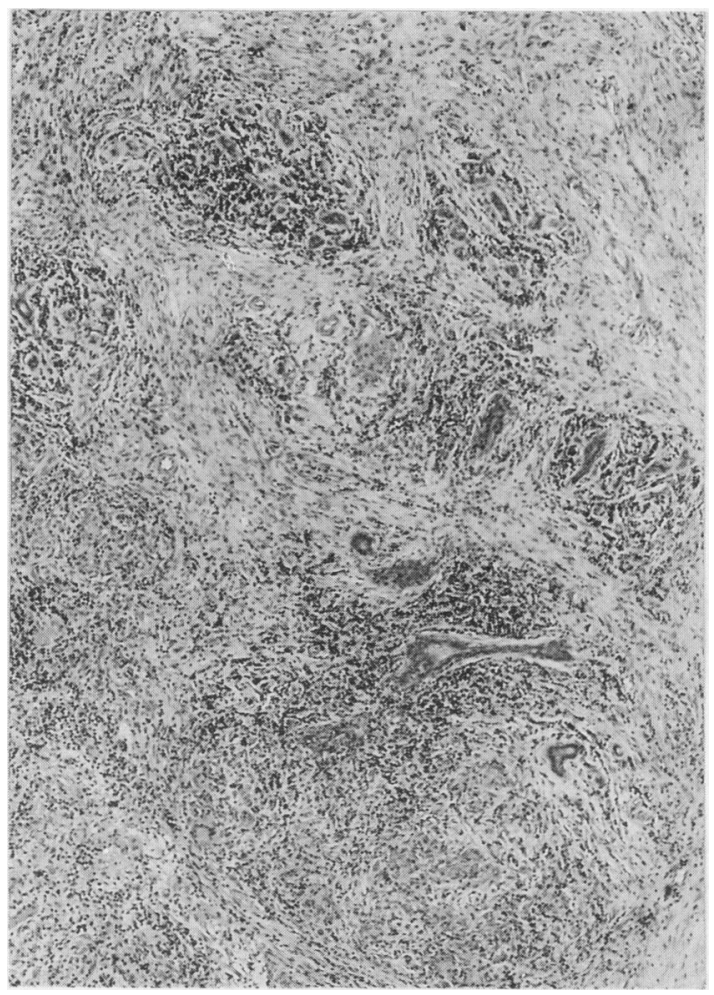

Fig 1 Granulomatous lobular mastitis (case 8). Diffuse granulomatous inflammation centred on lobular units. (Haematoxylin and eosin.)

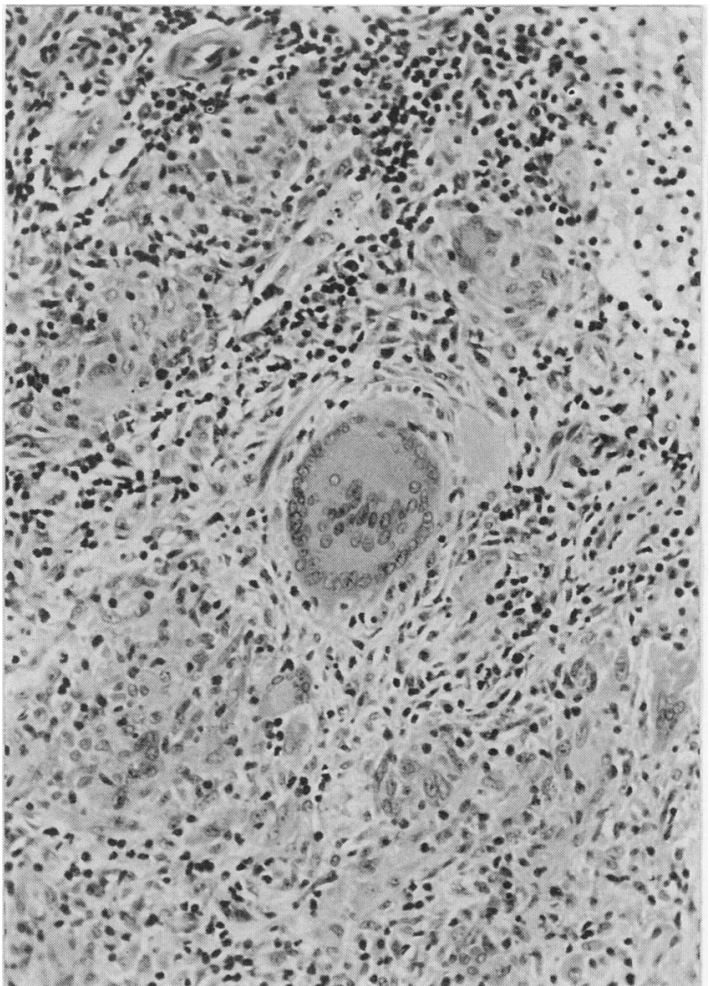

Fig 2 Granulomatous lobular mastitis (case 5). Giant cells are conspicuous. Lobular architecture is difficult to see in this field due to florid inflammation. (Haematoxylin and eosin.)

$1,4,10,16)$. Refractile or birefrigent material was not identified, nor was there evidence of squamous metaplasia or keratin formation. In only two cases (one in each group) was any residual lactational differentiation identified; in these two cases occasional lobules showed lactational features. The patient with granulomatous mastitis (case 8), had a raised prolactin concentration. Although the inflammatory process was generally intense in both groups (table 3), a notable difference was that all cases of periductal mastitis showed concomitant duct ectasia, while only two of the cases of granulomatous mastitis showed any duct dilatation (table 3). Features such as abscesses, lipid in granulomata, fat necrosis, and necrosis in granulomata were seen equally often in both groups. One case from each group showed occasional lactational lobules.

\section{Discussion}

Granulomatous mastitis has characteristic histological features, the most important of which is 


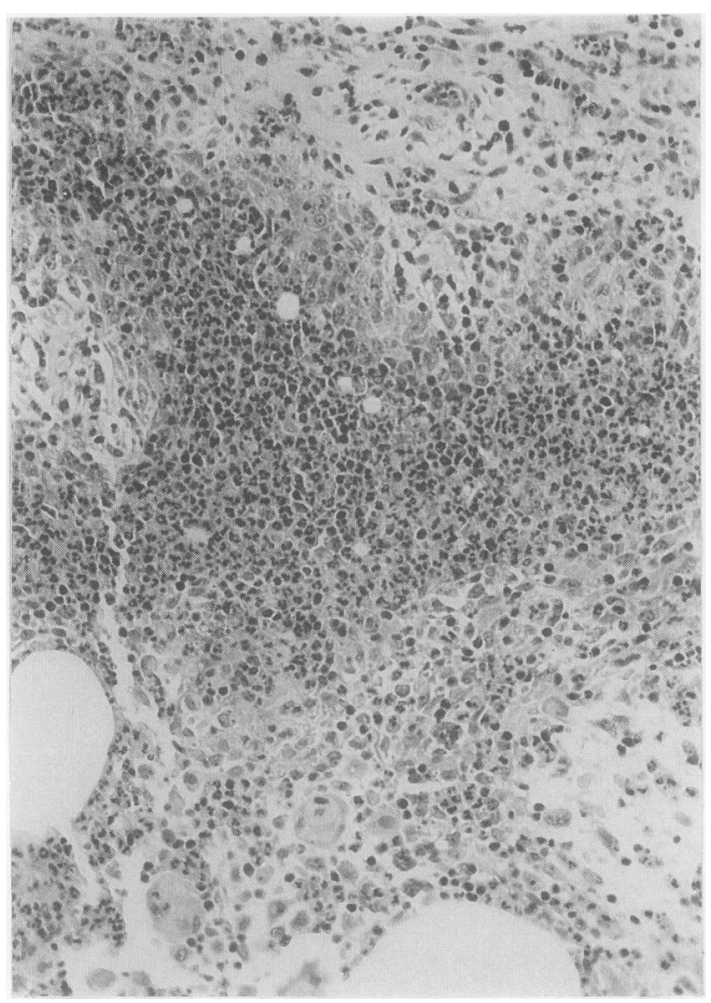

Fig 3 Granulomatous lobular mastitis (case 8). There is abscess formation. Small and large lipid droplets are present, represented by clear spaces. (Haematoxylin and eosin.)

predominantly lobular inflammatory disease, in contrast to the granulomatous variants of DE/PM. Although often related to recent pregnancy and lactation, two of our cases occurred 15 years after the last pregnancy, and so the term "post-lactational granulomatous mastitis," recommended recently by Davies and Burton, ${ }^{11}$ may not always be appropriate. The term "granulomatous lobular mastitis" has the advantage of emphasising the single most important histological feature of this condition, and avoids the vagueness of "granulomatous mastitis" to which Davies and Burton objected. The cause of granulomatous mastitis is not known. A primary infectious cause seems unlikely, given that organisms have never been confirmed histologically or on culture, but it cannot be excluded. This possibility is supported by the recent demonstration ${ }^{13}$ that anaerobic bacteria may be isolated from many cases of duct ectasia. Although secondary infection can be a complication, what may seem clinically to be like wound infection may reflect continuation of the primary pathology, as seen in cases $2,4,5,8$ and 9.
It is essential to exclude known causes of granulomatous inflammation, and special stains for bacteria, fungi, and mycobacteria should be performed. In view of recent evidence that anaerobic bacteria may be associated with the lesions of DE/PM ${ }^{13}$ swabs for anaerobic culture should be obtained. The use of appropriate swabs and appropriate transport media is important to recover these organisms. Immediate inoculation into Robertson's cooked meat broth has been shown to increase the recovery and range of organisms from wound swabs. ${ }^{1314}$ Although anaerobic organisms were not isolated from the cases of DE/PM in the present series, it should be noted that in these particular cases special transport media were not used. In addition to the above, specific cultures for mycobacteria should be set up.

The mean age of our patients with granulomatous mastitis (28.4 years) was comparable with that of previously reported cases ( 33 years) and was less than the ages of our patients with DE/PM (mean 45 years). Patients with granulomatous mastitis were all parous, with more children than patients with DE/PM. We confirm the previously reported association with recent pregnancy. ${ }^{2}$ There were two notable exceptions (cases 8 and 9), both of whom developed granulomatous mastitis 15 years after their last pregnancies. In one of these patients gross drug induced hyperprolactinaemia was probably important, but the other patient had a normal serum prolactin concentration. A case of granulomatous mastitis has been reported in association with hyperprolactinaemia. $^{8}$

The size of the palpable lesion in our cases of granulomatous mastitis was very variable, and thus resembled previously reported cases of granulomatous mastitis and our cases of DE/PM. In none of our patients with granulomatous mastitis were both breasts affected (although one quarter of published cases reported bilateral disease), and there was no tendency for one side to be affected more often than the other. Of unilateral cases, considering our own and published cases, the right breast was affected in 12 and the left in 15. Four of our nine cases of granulomatous mastitis were considered to be malignant on $N$ clinical grounds; this agrees with previous experience; 10 of 21 published cases were considered to be malignant, and a further four were "suspicious".

Other factors possibly relevant to the development of granulomatous mastitis that we considered included breast feeding and use of oral con- $\Phi$ traceptives. No relation emerges in either situation. Although more of our patients with granulomatous mastitis had used oral contraceptives than our patients with DE/PM, the age difference between the groups may have accounted for this.

Many authors have noted the troublesome course 


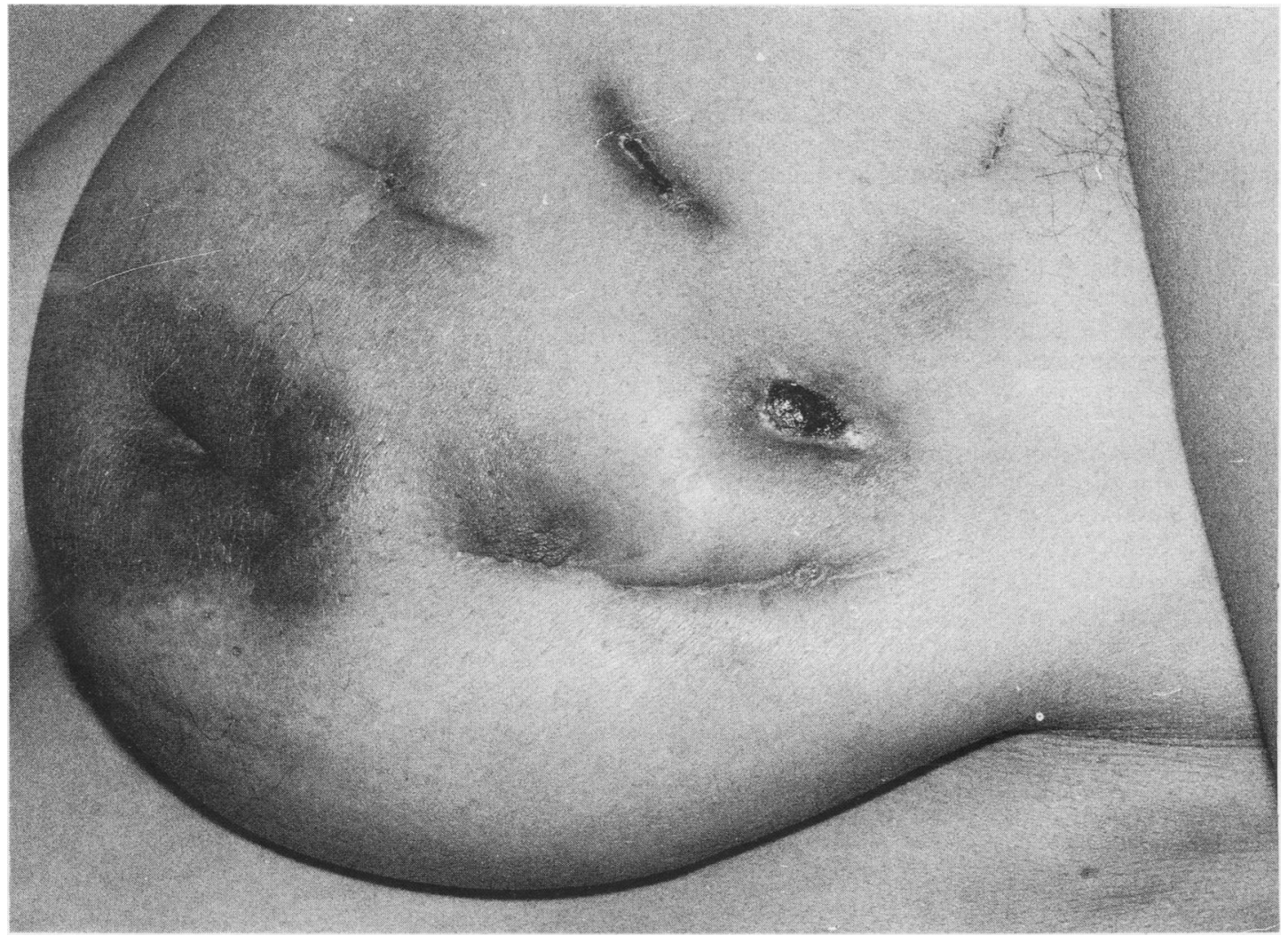

Fig 4 Left breast of case 8 after five months of treatment including two biopsies, four drainage procedures, several weeks of antibiotic, and systemic steroid use. Continuing active inflammation is associated with sinus formation. This picture typifies problems of granulomatous lobular mastitis. Nipple inversion is bilateral and has been present for many years.

Many authors have noted the troublesome course pursued by granulomatous mastitis, with 10 of 15 published cases, in which the number of operations was recorded, having more than one operation. Several of our patients conformed to this pattern which was exemplified by case 7, who experienced persistent active disease affecting the left breast. Fig 4 shows the condition of the breast after five months of treatment, including four drainage procedures, two biopsies, course of antibiotics, and a relatively brief course (14 days) of prednisolone. Although not all patients with granulomatous mastitis follow such a course, in those that do, the disease seems to take several years to become inactive, but detailed long term follow up is not available for many cases. One of the patients reported by Brown and Tang ${ }^{5}$ had problems intermittently for at least 13 years.

It seems from DeHertogh's case and case 7 of Fletcher $e t a l^{2}$ that drug treatment may be helpful and that further evaluation is desirable. Radical local excision, which has previously been recommended in refractory cases, ${ }^{3}$ should probably be deferred in any case until adequate trials of drug treatment-for instance corticosteroids-have been made. DeHertogh's patient received $60 \mathrm{mg} /$ day of prednisolone; the therapeutic trial of steroids in our case 7 was curtailed by anxieties about a possible infectious component to her illness, and more intensive treatment might possibly have been more effective. This point is likely to arise in other cases, so that if the diagnosis of granulomatous lobular mastitis is known or suspected, part of any resected material should be reserved for culture for tuberculosis and aerobic and anaerobic organisms. Histological examination for fungal organisms should also be performed. If these investigations are all negative, treatment with corticosteroids could be used with greater confidence.

In any granulomatous inflammation of the breast sarcoidosis enters the differential diagnosis and Kveim testing, chest radiography, and measurement 
of serum angiotensin converting enzyme $(\mathrm{ACE})^{15}$ and lysozyme $^{16}$ may be appropriate. There are no published data on ACE and lysozyme serum activities in granulomatous mastitis, but raised values have been described in a case of sarcoidosis with mammary disease. ${ }^{17}$ This published case showed a lobular pattern of granulomatous inflammation, and it is therefore of interest that both serum ACE and lysozyme were within normal limits in case 3 .

None of our cases was diagnosed clinically before biopsy, which re-emphasises the importance of awareness among pathologists of this unusual but distinctive disorder.

We thank Mrs Carolyn Brown and Mrs Fiona Govan for preparing the manuscript, Mr Alan Smith for technical work, and Dr AC Douglas for comments.

\section{References}

1 Kessler E, Wolloch Y. Granulomatous mastitis: a lesion clinically simulating carcinoma. Am J Clin Pathol 1972;58:642-6.

2 Fletcher A, Magrath IM, Riddell RH, Talbot IC. Granulomatous mastitis: a report of seven cases. J Clin Pathol 1982;35:941-5.

3 Koelmeyer TD, MacCormick DEM. Granulomatous mastitis. Aust NZ J Surg 1976;46:173-6.

4 Cohen C. Granulomatous mastitis: a review of five cases. $S$ Afr $J$ Med 1977;52:14-16.

5 Brown KL, Tang PHL. Postlactational tumoral granulomatous mastitis: a localised immune phenomenon. Am J Surg 1979;138:326-9.
6 DeHertogh DA, Rossoff AH, Harris AA, Economou SG. Prednisone management of granulomatous mastitis. New Engl $J$ Med 1980;303:799-800.

7 Carmalt HL, Ramsey-Stewart G. Granulomatous mastitis. Med J Aust 1981;1:356-9.

8 Rowe $\mathrm{PH}$. Granulomatous mastitis associated with a pituitary prolactinoma. Br J Clin Pract 1984;38:32-4.

9 Dalmark G. Lymphogranulomatose benigne. Un cas avec des alterations mammaires comme seul symptome. Acta Clin Scand 1942;86:168-78.

10 Milward TM, Gough MH. Granulomatous lesions of the breast presenting as carcinoma. Surg Gynaecol Obstet 1970;130:478-82.

11 Davies JD, Burton PA. Post-partum lobular granulomatous mastitis. J Clin Pathol 1983;36:363.

12 Dixon JM, Anderson TJ, Lumsden AB, Elton RA, Roberts MM, Forrest APM. Mammary duct ectasia. $B r \quad J$ Surg 1983;70:601-3.

13 Bundred NJ, Dixon JM, Lumsden AB, et al. Are the lesion of duct ectasia sterile? Br J Surg 1985;72:844-5.

14 Miles RS, Hood J, Bundred NJ, Jeffrey RJ, Davies GC, Collee JG. The role of Robertson's cooked-meat broth in the bacteriological evaluation of surgical specimens. $J$ Med Microbiol 1985;20:373-8.

15 Studdy PR, Lapworth R, Bird R. Angiotensin-converting enzyme and its clinical significance. J Clin Pathol 1983;36:938-47.

16 Pascual RS, Gee JBL, Finch SC. Usefulness of serum lysozyme in the diagnosis and evaluation of sarcoidosis. $N$ Engl $J$ Med 1973;289:1074-6.

17 Banik S, Bishop PW, Ormerod LP, O'Brien TEB. Sarcoidosis of the breast. J Clin Pathol 1986;39:446-8.

Requests for reprints to: Dr JJ Going, Department of Pathology, University Medical School, Teviot Place, Edinburgh EH8 9AG, Scotland. 